Volume -X, Issue-01, January-June, 2015

\title{
Socio-Economic Status and Current Business Situation of Cane Based Furniture Entrepreneurs in Bangladesh: An Empirical Study
}

\author{
MD. KAMRUL HASAN ${ }^{*}$ \\ NAYEEMA MASWOOD NEELA ${ }^{* *}$
}

\begin{abstract}
Cane based furniture business is one of the least researched areas in Bangladesh. The purpose of the present study is to appraise socio-economic conditions and business policy of cane based furniture in the study area of Sylhet city, Bangladesh. The study reveals that $57 \%$ of cane furniture enterprises is small, 36\% is medium and 7\% is large in size. The average investment, production and profit range around Tk. 2, 80,000, Tk. 2,21,916 and $T k$. 22,500 respectively per enterprise. Sofa, chair and rocking chair are the most demanded and profitable items. The study also reveals that $51 \%$ of entrepreneurs are suffering from shortage of capital and raw materials, whereas $35 \%$ are suffering from unskilled labor and adequate transportation facilities. High price due to high cost, low demand, archaic and common design, less promotion are the major problems of cane furniture. The study suggests that entrepreneurs should create demand for cane furniture among all classes of people through proper promotional programs, newest design, adding new features, improving quality and making the product available to all over the country through proper distribution. Government should patronize this industry by giving financial and institutional supports.
\end{abstract}

Keywords: Cane enterprises, Cane furniture, Family business, Sale and profit, BSCIC, S.C.C area

\section{INTRODUCTION}

Cane is one of the important natural forest resources in Bangladesh. The importance and usage of this stuffs rank next to timber and bamboo. Its natural qualities allow it to be tanned, shaped, and bent to make long-lasting and gorgeous looking furniture. Cane can be best adorned in making furniture with

\footnotetext{
*Assistant Professor, School of Business and Social Sciences, Sylhet International University, Sylhet-3100, Bangladesh, E-mail: khasanzia@yahoo.com

** Assistant Professor, School of Business and Social Sciences, Sylhet International University, Sylhet-3100, Bangladesh, E-mail: nayeema.neela@yahoo.com
} 
creative design and artistry subtly bears testimony to the glorious tradition of handmade artifacts in Bangladesh. Such furniture ranges from dining tables to dressing tables or easy chairs to rocking chairs or from dress hangers to shoe racks. Artisans gifted with artistic bent of mind employ combination of manual and mental labor in making high quality cane furniture like chairs, tables, sofa sets, book shelves, beds, corner shelves, partitions, wardrobes, almirahs, showcases, plantation cases, glass frames, trays, trolleys and show pieces.

A number of small and medium enterprises (SMEs) based on cane are operating both in rural and urban areas in Bangladesh. They are providing direct economic opportunities for the poor or the middle-income section of people through employment and income generation schemes all over the country. Bangladesh Small and Cottage Industries Corporation (BSCIC) conducted a survey in 1981 and reported that there are 322,000 cottage industry units in Bangladesh producing 160 different types of goods (Banglapedia, 2008). Cane based enterprises are one of the most flourished businesses in the northeastern region of Bangladesh. Cane enterprises have become an important income generating business for poor and middle class people. Bamboo and cane goods cover the largest sub-sector of handicrafts which provided employment for about 135,000 persons in 2000 (BSCIC).

Cane items have listed in the exportable goods. The country earns a huge amount of foreign currencies through exporting cane made items that earned Tk. 258.6 million in 1999-2000. The furniture market of Bangladesh is changing with the change of fashion and demand of the consumers. Hence, there is a great scope of earning foreign exchange and also to reduce unemployment problem by producing and marketing cane products. Further the raw materials will be properly used through the development of this industry. Despite high socioeconomic importance, little attention has been paid by the government. The researchers are here to explore the different aspects of cane based furniture in Bangladesh. Therefore efforts are needed to investigate state of affairs of cane based furniture in the northeastern region of Bangladesh. The study will help in making right decision in investing to this industry and the government and non government organization should realize the necessity of providing expertise to the cane enterprises of the country.

\section{LITERATURE REVIEW}

Rattans called cane is one of the important natural resources of Bangladesh forests and homesteads (Ara, 1997a). Eleven species of cane are reported under two genera: Calamus and Daemonorops and all species are found growing naturally in the forest (FAO, 1993). Cane is grown in the north-eastern hill forests of Chittagong, Cox's Bazar, Chittagong Hill Tracts and Sylhet (Ara, 
1997b). In Bangladesh cane is procured from the state forest by local people paying of royalties to the Forest Department of Bangladesh (Patric et al. 1994). Calamus guruba (jali bet or sundi bet) and Calamus tenuis (bet, jayo) are used in making furniture in Bangladesh (Banik, 1998). The demand of well processed and high-quality canes is going up in the global market and it is alleged that the demand is three times more than that of supply (Nuruzzaman, 2001). The climatic condition of Bangladesh is very suitable for cane production (BBS, 2002). But this natural resource is getting depleted at an alarming rate (Banik : 1998). Rattan is one of the materials of cottage industries and this resource adds considerable amount of revenue to rural households (Mohiuddin et al, 1986). The authors (Nath et al, 2000; Akther et al,1997; Bakht,1984; Hossain,1984) have studied on different aspects on cane and bamboo based industry in Bangladesh. The profitability of cane based furniture industry is very high and the cost benefit ratio is 1:6 (Alamgir et al, 2006). Cane is an environmental friendly, strong and naturally beautiful material. Maintenance of it is very simple too. (Wright Gen, 2008).

\section{OBJECTIVES OF THE STUDY}

The objectives of the study are;

i. To delineate the nature of cane based furniture Sylhet city corporation (SCC) enterprises and socio-economic conditions of entrepreneurs in S.C.C area

ii. To explain the existing business policy of cane based furniture in the area

iii. To find out the opportunities and problems faced by the entrepreneurs of cane based product business in the study area

\section{METHODOLOGY OF THE STUDY}

The study is confined to Sylhet City Corporation (SCC) area of Bangladesh. The study is exploratory as well as descriptive in nature. Because, different aspects and issues of the entrepreneurs and enterprises of cane furniture has been described. The study is based on both primary and secondary data. For collecting primary data, 50 enterprises of cane furniture have been selected through convenient sampling method from different areas of SCC in the year 2013 (July). A structured questionnaire was used to collect data having both the close-ended and open-ended questions. Personal interview method has been used to get data. The secondary data used in the study have been collected from the publications of BSCIC, Bangladesh Bureau of Statistics, The concerned ministry and published thesis, Journal, Daily Newspapers, etc. The collected data have been analyzed through some common statistical techniques. 


\section{ANALYSES AND FINDINGS OF THE STUDY:}

\subsection{Demographic and socioeconomic characteristics of the entrepreneurs}

There are many local and tribal people doing job in cane furniture industry in Sylhet. About 150 entrepreneurs are directly and indirectly engaged in production and processing of cane and cane based furniture in study area.

TABLE 1

DEMOGRAPHIC AND SOCIOECONOMIC CHARACTERISTICS OF ENTREPRENEURS

\begin{tabular}{l|c}
\hline \multicolumn{1}{c|}{ Characteristics } & Percentage-share \\
\hline Ownership type & 26 \\
Self initiated & 74 \\
Family tradition (inherited) & \\
Age & 25 \\
15-30 year & 56 \\
30-50 year & 19 \\
50- above & \\
Education level & 0 \\
Illiterate & 78 \\
Bellow SSC & 16 \\
Graduate & 4 \\
Post Graduate & \\
\hline
\end{tabular}

Source: Field survey, 2013

The age of $56 \%$ entrepreneurs range between $30-50$ years, $25 \%$ entrepreneurs' ranges between 15-30 years, and that of only $19 \%$ entrepreneur is over 50 years. In fact, it is difficult or impossible to run a business like cane enterprise without having at least basic education. The analyses of educational qualification of the entrepreneurs reveal that $78 \%$ entrepreneurs' education level is below S.S.C or equivalent, $16 \%$ have graduated and only $4 \%$ have got post graduation degree and no entrepreneur was illiterate. About $74 \%$ respondents informed that they are running family business that have been inherited from forefathers and only $26 \%$ of the entrepreneurs have started the business in the study area by themselves. 


\subsection{Nature and characteristics of enterprises:}

The cane based enterprises are located at different area in the Sylhet. About 250 enterprises of different nature which are directly engaged in production, processing and marketing of cane and cane based furniture in Sylhet city corporation area (Field survey). Out of 50 enterprises about $67 \%$ enterprises were established before 11-20 years, $16 \%$ before $1-10$ years, and the remaining $17 \%$ before $21-30$ years.

TABLE II

\section{NATURE AND CHARACTERISTICS OF ENTERPRISES}

\begin{tabular}{l|c}
\hline Characteristics & Percentage \\
\hline Age of establishment & 16 \\
01-10 year & 67 \\
11-20 year & 17 \\
21-30 year & \\
Nature of functions & 10 \\
\hline Only production & 18 \\
Production and Retailing & 70 \\
Production and Retailing and whole selling & 2 \\
Exporting & \\
Volume of primary capital & 54 \\
Tk 2000-50000 & 27 \\
Tk 50,0000- 100,000 & 17 \\
Tk 100,000- 150,000 & 4 \\
Tk 150,000-200,000 & \\
Average investment Tk 78,000 & \\
Volume of present investment & \\
Tk 1,00,000-200000 & 41 \\
Tk 2,00,000-300000 & 29 \\
Tk 3,00,000-400000 & \\
Tk 4,00,000-600000 & \\
Average investment Tk 2,80,000 & \\
\hline
\end{tabular}




\begin{tabular}{lc}
\hline Characteristics & Percentage \\
\hline $\begin{array}{c}\text { Size of enterprises } \\
\text { Small }\end{array}$ & 63 \\
Medium & 33 \\
large & 4 \\
Volume of production & \\
Tk 20,0000- 50,000 & 17 \\
Tk 50,0000- 100,000 & 53 \\
Tk 100,000- 200,000 & 30 \\
Average production Tk. 2,21,916 & \\
\hline
\end{tabular}

Source: Field survey, 2013.

The economic analyses of the entrepreneurs show that only $10 \%$ entrepreneurs are involved in producing, $18 \%$ in retailing and $70 \%$ in producing, whole selling and retailing where only $2 \%$ of them are exporting. The study on volume of investment reveal that at present the total investment of $41 \%$ enterprises ranges between $\mathrm{Tk} 1,00,000-200000$; the total investment of $29 \%$ enterprises varies between Tk 2,00,000-3,00,000; the total investment of $21 \%$ enterprises fluctuates between $\mathrm{Tk} 300,000-400,000$; and the total investment of only $9 \%$ enterprises ranges between $\mathrm{Tk} 400,000-600,000$. The average investment of the sampled enterprises in cane furniture business in Sylhet city is TK. 2,80,000. The survey on initial capital published that the initial capital of $54 \%$ enterprises was only between Tk 20000-50000, starting capital of $27 \%$ enterprises varied between Tk 50,000-1,00,000, starting capital of $17 \%$ enterprises fluctuates between $\mathrm{Tk}$ 1,00,000-1,50,000; and only starting capital of $4 \%$ enterprises varied between $\mathrm{Tk} 1,50,000-2,00,000$. And the average primary capital of the 50 enterprises was only Tk.78, 000. The number of small enterprises is of the highest percentage (57\%), whereas $36 \%$ of the enterprises are medium and $7 \%$ are large in terms of labor. The field survey reveal that the monthly production volume of $53 \%$ entrepreneurs fluctuates between Tk $50,000-1,00,000$ and that $30 \%$ of entrepreneurs fluctuates between $\mathrm{Tk} 1,00,000$ $2,00,000$, while the production volume of the rest range from Tk 10,000-30,000. Average production is Tk 2,21,916. 


\subsection{Production process and nature of cane furniture}

Cane furniture adorned with creative design and artistry subtly bears testimony to the glorious tradition of handmade artifacts in Bangladesh. Such furniture ranges from dining tables to dressing tables or easy chairs to rocking chairs or from dress hangers to shoe racks. The image of different flowers, such as Rajanigandha, Kadam, Suryamukhi and Shapla or of the moon and stars, boats, and the waves of river, are manifested in the exterior decoration of the body of such furniture.

\subsubsection{Production and cultivation of raw materials}

Cane is the main raw materials of cane based industry. Cane season is from December to April/May. The climate condition of Bangladesh is very suitable for cane growing (BBS:2002). Canes are propagated both by vegetative means and seeds. Suckers are planted for vegetative propagation. For seed propagation seedlings are raised in nurseries and then planted in fields. The fleshy pulp of the seed is first removed and then the seeds are sown in seedbeds where they germinate within a few weeks. When the seedlings attain a height of $0.75-1 \mathrm{~m}$, they are planted in fields during the Moonson season. By 2-3 years seedlings grow to the size of a clump. Within 7-8 years the cane is ready for harvesting. Generally, no intensive management is required. Irrigation, if required, and fertilization are done at an early stage of plantation. Generally, canes grow in the north- eastern hilly forests of Chittagong, Cox's bazar, Chittagong hill tracts \& Sylhet. High quality cane is also produced in Comilla, Bogra, Jessore and Rajshahi. In Bangladesh, cane is not cultivated commercially. It grows in bushes and jungles in small amount and the quality is not that good. Recently, the forest department has started cane plantation in many forest areas.

\subsubsection{Types and sources of raw material and their use}

Cane is the main raw material for cane furniture industry. There are 600 varieties cane consisting of 13 species in the world. Out of the 13 species only two viz. Calamus (Jali bet) and Daemonorops (golla bet) grow in Bangladesh. Generally, canes grow in the north- eastern hilly forests of Chittagong, Cox's Bazar, Chittagong hill tracts and Sylhet. High quality cane is also produced in Comilla, Bogra, Jessore and Rajshah. Swamp forest of Sylhet region is also the home ground for cane. Red lands of Gowainghat, Jaintapur, Companigonj, Jakigonj and Jaflong areas are rich in cane. 
TABLE III

THE TYPE AND USAGES OF RAW MATERIALS.

\begin{tabular}{l|l|l|c}
\hline $\begin{array}{l}\text { SL. } \\
\text { No }\end{array}$ & Source of raw materials & Types of cane & $\begin{array}{c}\text { Percentage of } \\
\text { usages }\end{array}$ \\
\hline 1 & Local source (Village and Forest) & Golla \& Jali & 40 \\
2 & Regional source & Golla \& Jali & 25 \\
3 & Imported source & Golla \& Bdudum & 35 \\
\hline
\end{tabular}

Source: Field Survey, 2013.

Among various species of cane, Golla (Daemonorops jenkisianus) and Calamus (Jali bet) are mostly used. Different varieties of cane are used for different purposes. Jali bet is used for weaving, netting, binding, crossing and design work. Golla bet is used for framework, structure, support and bracket and design also. Bhudum bet is mainly used mainly for hard structural works. Some enterprises also use bamboo and patipata (Schumannianthus dichotoma) as substitute of cane. Now-a-days, synthetic binding materials are also used in the cane enterprises as they last longer and cheaper in price.

\subsubsection{Processing of raw materials for finished products}

Cane is the material, but wicker is the process of weaving the rattan or other materials into the finished goods. Cane is strong, durable and easy to work with. It requires simple machines and tools in making them a popular choice of material for furniture. Cane needs to be duly processed for protection against wood-mite and fungus. Once cut, the cane is soaked in water for six to seven days to separate the bark from the stalk (cane). It is then washed vigorously and dried in the sun. The soaking and drying process is then repeated in order to increase the flexibility of the cane. There are two weaving techniques, one using whole cane and the other using split cane stalks. By splitting quantities of cane into thin layers and using the split lengths to bind cane, artisans are able to sculpt and strengthen the products. Artisans use hammers, knives and local tool called a 'Bhromore' while working the cane. They also use bamboo nails, rather than iron nails, for joining. Usually, cane takes good shape in 4 to 5 years when they become appropriate for use in high quality work. Moderately ripe canes have less water content in them and are flexible. Too ripe canes break while being worked on. Articles made with too young canes get cracked and shrunk and articles made of such cane are affected with wood-mites. Cane needs to be duly processed for protection against wood-mite and fungus. The quality of a cane product also 
depends on the quality of dye work on them. Make sure that they are properly aired and dried, as moisture and humidity can cause mould.

\subsubsection{Procurement of raw materials}

Raw materials for cane furniture are procured from different sources using different channels. The cane of state-owned forest is first procured by the listed traders (Mohalder) by open auction. After procurement from the forest the Mohalders then sell the cane to the wholesalers and the wholesalers then brought the cane by boat or truck to the local market at Ghashitula and Haripur of Sylhet for sale in retail. The entrepreneurs bought canes from the wholesaler in the village market. The private sources are divided into two categories: local and regional. The local sources of raw cane include the marshy areas of Sylhet where cane grows naturally. The growers brought the cane from different villages by head load, rickshaw vans or by boat to the market. The wholesalers procure the raw material from local growers through local collectors and then brought them to SCC and sell to various cane based enterprises.

Figure 1: The major market channels for the raw materials from all sources

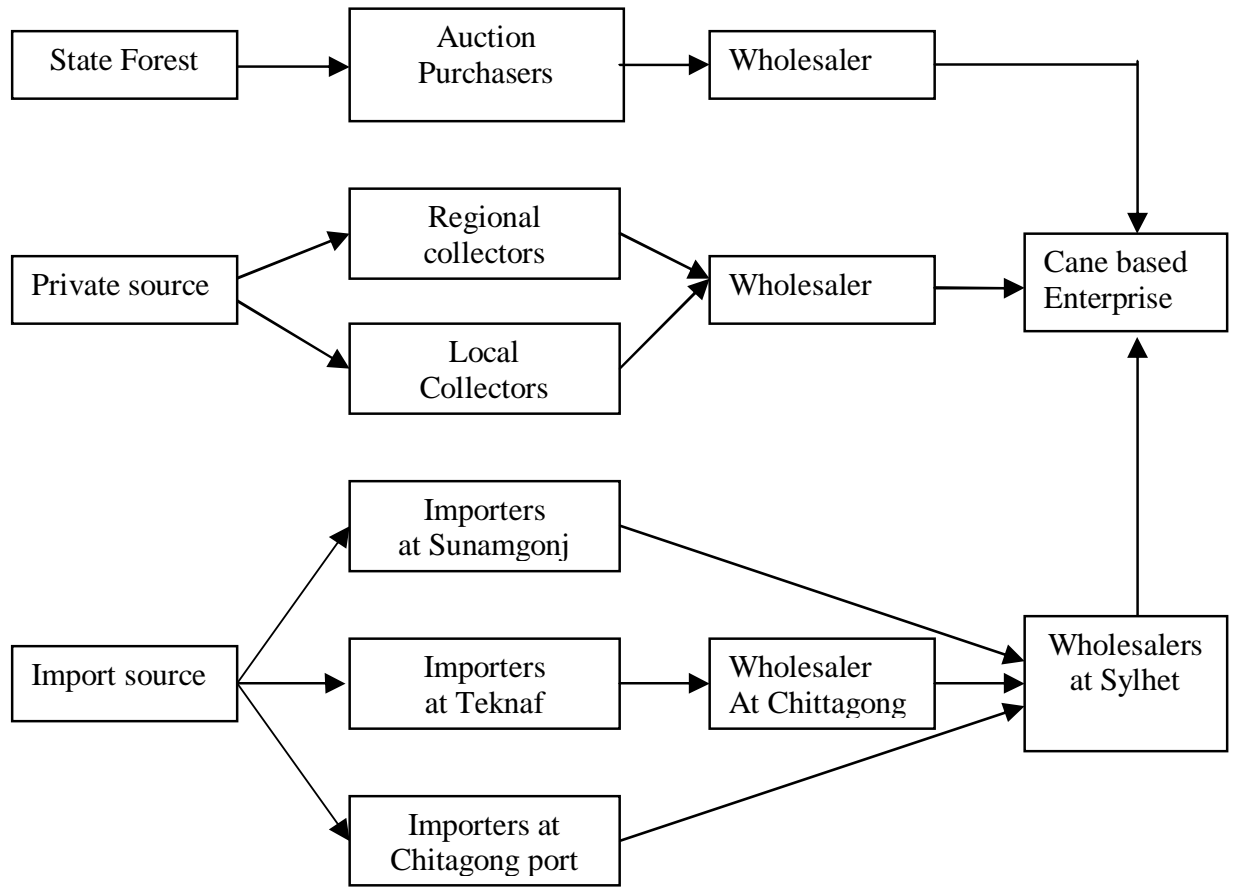

Source: Field survey, 2013 
The principal regional sources of cane are Chittagong Hill Tracts, Sunamgong, Haripur Bazar, Baralekha, Srimangal and Salutikor. The local traders (Mohajan) procure cane from regional sources and then sell to wholesalers. The entrepreneurs bought the cane from the wholesalers. The total cane supply of Ghashitula hat (a local market) comes from two sources. The local supply is about $75 \%$ and the remaining $25 \%$ of the total cane comes from Chittagong Hill Tracts. The raw cane traders also sell cane to the enterprises directly. The commission agents collect cane from Hills and homesteads of Chittagong Hill Tracts and they store the cane in their storehouse. The wholesalers buy cane from the commission agents and the enterprises procure from the whole seller directly and brought the cane by train or truck. Bangladesh imports cane from Myanmar, India, Indonesia, Malaysia and Singapore mainly by the traders of Chittagong. There is no agent or retailer in Sylhet. About $35 \%$ of total cane used by enterprises is imported. The study found that all of the enterprises purchase raw materials from the retailers located in the village markets. They usually collect from Ghashitula Hat (a local market) in two market days a week.

5.3.5. Costs and profit per unit of sale: A production is bundle of physical service and symbolic attributes design to produce consumer want satisfaction (Louis E Boove). In cane furniture industry, most common products in different size and nature are sofa set, dinning set, bed set, chairs, tables, divan, cradle, shelf and lamp stand. However, it is found that $86 \%$ enterprises produce Sofa, Chair, Rocking chair and Cradle. Sofa and Rocking chair are more selling items among all other produced items. In all category enterprises sofa is the highest produced items and the lowest produced item is bed. The price of the cane products varies from enterprise to enterprise and depends on number of labor involved, labor wage, cost of raw materials, cost of transportation, visual attraction and quality of products (Chaudhury, 1984; Mehta, 1981). The field survey has revealed that most of the producers of cane based furniture determine selling price on the basis of cost plus- profit method. Both production and selling are done at the same place, but larger enterprises have their own outlets in different market place of the city. A broad range of types of products, production cost, selling price and net average profit of different articles are given in Table-4, 
TABLE IV

PRODUCTS, PRODUCTION COST, SELLING PRICE AND NET PROFIT OF DIFFERENT CANE PRODUCTS.

\begin{tabular}{|c|c|c|c|c|}
\hline $\begin{array}{c}\text { Name of the } \\
\text { products }\end{array}$ & $\begin{array}{l}\text { Size range of the } \\
\text { products }\end{array}$ & $\begin{array}{l}\text { Average production } \\
\text { cost range per } \\
\text { article(Tk.) }\end{array}$ & $\begin{array}{l}\text { Average selling } \\
\text { price range(Tk.) }\end{array}$ & $\begin{array}{l}\text { Net average } \\
\text { profit } \\
\text { (Tk.) }\end{array}$ \\
\hline \multirow{3}{*}{ Sofa Set } & $60^{\prime \prime} \times 20^{\prime \prime} \& 22^{\prime \prime} \times 22^{\prime \prime}$ & $8000-10500$ & $8500-12000$ & 1000 \\
\hline & $54^{\prime \prime} \times 18^{\prime \prime} \& 20^{\prime \prime} \times 20^{\prime \prime}$ & $7000-8500$ & $7500-9000$ & 500 \\
\hline & $36^{\prime \prime} \times 18^{\prime \prime} \& 18^{\prime \prime} \times 18^{\prime \prime}$ & $4000-5500$ & $4000-7000$ & 750 \\
\hline \multirow[t]{3}{*}{ Dining Table } & $60^{\prime \prime} \times 48^{\prime \prime}$ Full size & $5500-7000$ & $6000-8000$ & 750 \\
\hline & $48^{\prime \prime} \times 36^{\prime \prime}$ Semi size & $4000-5500$ & $4500-6500$ & 750 \\
\hline & $84^{\prime \prime} \times 60^{\prime \prime}$ Double size & $7500-9500$ & $8000-10000$ & 500 \\
\hline \multirow[t]{2}{*}{ Bed } & $84^{\prime \prime} \times 48^{\prime \prime}$ Semi double & $5000-6500$ & $5000-7500$ & 500 \\
\hline & $84^{\prime \prime} \times 36^{\prime \prime}$ Single size & $4000-5000$ & $4500-5000$ & 250 \\
\hline \multirow[t]{2}{*}{ Chair } & Oval Shape & $550-650$ & $600-800$ & 100 \\
\hline & Disco size & $500-700$ & $600-900$ & 150 \\
\hline \multirow[t]{3}{*}{ Dolna } & Hanging & $700-900$ & $750-1000$ & 75 \\
\hline & Standing & $1000-1400$ & $1000-1600$ & 100 \\
\hline & Easy size & $1800-2400$ & $2000-2800$ & 300 \\
\hline \multirow[t]{3}{*}{ Rocking Chair } & Medium size & $1300-1500$ & $1400-1800$ & 200 \\
\hline & Small size & $300-500$ & $300-700$ & 100 \\
\hline & Book shelve & $600-900$ & $650-1000$ & 75 \\
\hline \multirow[t]{3}{*}{ Shelf } & Wall shelve & $800-1200$ & $1000-1400$ & 200 \\
\hline & Corner shelve & $1200-1600$ & $1500-2000$ & 350 \\
\hline & Tool size & $200-300$ & $250-400$ & 75 \\
\hline \multirow[t]{2}{*}{ Mora } & Appeal size & $200-300$ & $250-400$ & 75 \\
\hline & Fancy size & $300-400$ & $300-500$ & 50 \\
\hline \multirow[t]{2}{*}{ Tea table } & Full size & $700-1000$ & $800-1200$ & 150 \\
\hline & Semi size & $500-700$ & $500-800$ & 50 \\
\hline \multirow[t]{2}{*}{ Dressing table } & Single size & $3000-3600$ & $3500-4200$ & 550 \\
\hline & Family size & $4500-6000$ & $5000-7000$ & 750 \\
\hline \multirow[t]{2}{*}{ Divan } & $72^{\prime \prime} \times 24^{\prime \prime}$ & $4700-6200$ & $5000-7000$ & 550 \\
\hline & $60^{\prime \prime} \times 18^{\prime \prime}$ & $3200-4300$ & $3500-5000$ & 500 \\
\hline Lamp stand & Different style & $250-400$ & $300-500$ & 75 \\
\hline
\end{tabular}

Source: Field survey, 2013. 
Almost all enterprises produce their products on the basis of order from customers. Larger enterprises get production orders from different parts of the country and even from abroad. In terms of product demand winter is better, since tourists come from all around and thus the market demand is increased manifold. During these days the enterprises employ more labor force to meet the increased demand of products. It shows that Production cost of a large size sofa set is about Tk 8,000 to Tk. 10,500 and net average profit is Tk 1,000. Chairs of different types and sizes are also produced at different costs (starting from Tk 550 to 900 ) and sold at a margin of about Tk 100-150. The study has found that the monthly sales volume of $71 \%$ sampled enterprises varied between $\mathrm{Tk}$ 1,00,000-1,50000; the sales volume of $29 \%$ enterprises ranges between Tk. 1,50000-3,00,00; and the average monthly sales volume is Tk 2,00,000 per month. The average monthly profit of $46 \%$ enterprises varies between Tk 2000030000 and that of $29 \%$ of the enterprises range between Tk 10,000-20,000. In this case the average monthly profit is $\mathrm{Tk} 18,500$.

\section{PROBLEMS FACING EXPANSION OF CANE BASED FURNITURE BUSINESS}

As far as the production of cane and cane furniture are concerned, Bangladesh has some advantages in cane furniture business. Cane furniture is environment friendly, strong and long-lasting and gorgeous looking furniture. Maintenance is very simple too. In addition, the demand for well processed, good quality canes are going up in the world market and it is assumed that the demand is three times higher than the supply. Due to unemployment problem, the country enjoys low labor cost for all aspects of this business. Despite, this paper identifies some core problems regarding the cane based furniture business in the study area.

6.1. Financial Problem: Weakness remains due to the lack of financial and institutional support, instability of market demand. Most of the enterprises are medium and small in size. They don't have enough capital for expansion their business. The survey revealed that only 9 pc entrepreneurs gets governments and non government loan supports and almost all (91\%) of them don't get any support. Therefore the entrepreneurs suffer from financial facilities like short term and long term loan from government, non government institution.

6.2. Inconsistency in supply of raw materials: In Bangladesh, cane is not cultivated commercially. The country has to import good quality cane from outside, which raises the price of cane products. The price of cane, oil and other chemicals used in production are gradually increasing day by day. For this reason entrepreneurs are leaving their existing business. 
6.3. Obsolescence: It is difficult or impossible to run a business like cane enterprise without having at least basic education. The higher educated people are not interested in this business. The survey revealed that most of the (60\%) of entrepreneurs are low educated and their qualification is up to SSC. As a result they have become habituated in producing old and obsolete model production.

6.4. Low wages: The labors do their job in different level of production such as cane processing, making structure and giving the finishing touch. At different levels the wages range from Tk 30-120 per day, on an average. Due to this low wage, many labors are switching on to other job

6.5 High price due to high cost: The enterprises need skilled labor, oil and others chemicals in production resulting high cost of production. Producer face problem in pricing the product and failed to earn desired rate of return due to low demand for high price. The survey revealed that about $40 \%$ of enterprises face such type pricing problem and they are not interested in doing this business.

6.6. Low demand: Actually cane furniture is not popular to all classes of people. Due to low demand and high cost most of the producers can't achieve with their target sale and profit. Beside this poor and common design, low quality is the major problem to expand this business to all classes of people. As a result day by day they become de-motivated to carry on this business.

6.7. Inconvenient design and structure: The structure of cane furniture is not convenient to transport. During transportation it needs extra cares. We have found that $34 \%$ entrepreneurs are facing distribution problems in transporting. For that reason wholesale and individual retail business involvement is low in here.

6.8. Adaptation of technology: Moreover, there is always addition of technologies in different stages of production of cane furniture in the world. But the entrepreneurs are not exposed to state-of-the-art technologies required to improve their production

6.9. Threats of substitute products: Availability of substitutes is a top-level threat to cane products. Substitutes like plastic furniture are sold comparatively at lower cost; as a result, many customers move towards those of cheap articles.

\section{CONCLUSIONS AND RECOMMENDATIONS}

Cane furniture is environmentally friendly, strong, naturally beautiful, longlasting and gorgeous looking furniture. Maintenance is very simple too. If cared for properly, cane furniture can last for many years, or even decades. The industry has a number of desirable attributes of appropriateness in the context of prevailing socioeconomic conditions of the country. But because of various constraints, this industry is not flourishing at a desired pace. Considering the employment and income generation opportunities for the poor or the middle- 
income section of people throughout the countries government should give top most priority to this industry.

Cane products are in great demand throughout the world. Bangladesh has attained a considerably good position in cane crafts through participation in a number of international fairs that helps us to earn a huge amount of foreign currencies. But at present two hundred year-old industry is facing a threat. The following recommendations can be made to improve the cane industry sector in Bangladesh in general, and in the study area in particular.

7.1. It is found that capital problem is the main cause of low production, low promotion and small scale in business. Government should patronize this industry by giving logistic support. Government should realize that this industry can be a source of foreign revenue, and create job opportunity. Financial and institutional support should be ensured both by government and by private sectors. Fund allocation in favor of artisans engaged in cane industries can be increased. Mechanism can be developed to finance the entrepreneurs, especially in financially hard situations.

7.2. It is found that major portion of raw materials is collected from out of greater sylhet. The producers can combined or individually produce cane that will reduce the dependency on other to supply available raw materials. The government agencies (i.e. Forest Department) should ensure sustainable supply of quality raw material by raising cane plantation in forest area. There are many hilly areas which are unused in Sylhet. The producers can combined or individually produce cane that will reduce the dependency on external sources for the supply of raw materials.

7.3. The study has revealed that $74 \%$ products are consumed by middle class people and only $7 \%$ are consumed by lower class people. So, all the enterprises should create new demand in upper and lower class customers. For that situation suggestion may be given to produce separate sets of superior quality products with various designs, set high price for higher class people. Low price can be set for middle and lower class people with medium and low quality products.

7.4. The study has also revealed that most of the customers think major cane furniture as obsolete, poor and ordinarily designed. So all enterprises should adopt new designs, new features to consider the customer needs. Government can establish separate institute to carry research, training for the workers on various aspects of product development and marketing, including the improved processing technology.

7.5. The study reveals that the demand of this product is low in the market. Awareness should be created among the people in favor of cane-based cottage industry and their products. In this case mass media can play prime role. Bangladesh Small and Cottage Industries Corporation (BSCIC) and other organizations can arrange trade fairs for these products throughout the country to develop and expand a local market

7.6. For better production cane furniture need skilled labor. Due to low labor wages many young men are switching to other profession. Though, it is the part of small and cottage industry, village women can be involved in production. Government also can establish separate institute to carry research, training for the workers both men and women on various aspects of product development. 
7.7. In the study it is found that both the producers and customers face problems of high cost. In cane furniture cost also increases due to low demand and low production. If the enterprises can create demand then production will increase and per unit cost will decrease. So enterprises should create demand all over the country through proper promotion and mass distribution.

7.8. In Sylhet city there is no association of cane furniture entrepreneurs. The entrepreneurs can form an independent organization that will help to protect their interest and expand their business.

\section{REFERENCES}

Akhter, K., B.C. De, S.R. Dasgupta and Younuszzaman, M. 1992, 'Natural durability and treatibility of 10 village tree species', Bulletin 4 Wood Preservation Series, 46: 63-74.

Alam, K.S. and Azad A.K. 1996, 'Marketing of cosmetic products in Dhaka city: A case study', Dhaka University Journal of Business Administration, 17(1): 173-182.

Alam, M. and Y. Furukawa. 2009, 'Cane enterprises as family business in Bangladesh: A case study', Electronic Journal of Family Business Studies (EJFBS) 3(2).

Alamgir, M. and Jasimuddin, M. 2006, 'Economic profitability of cane based furniture enterprises of Chittagong City corporation area', Bangladesh. Journal of Foresty Research, 17(2): 153-156.

Anon 1980, Rattan: A report of a workshop held in Singapure, Canada: International Research Centre.

Ara Roshann1997a, Taxonomy and ecology of rattan in Bangladesh. Malaysia: Serdang

Ara Roshan, 1997b, Silviculture, improvement and conservation of rattans in bangladesh, Malaysia: Serdang.

Azad, M. 2002, Status and marketing of cane products in Khulna City Corporation, Master's thesis, forestry and wood technology discipline. Khulna: Khulna University

Banglapedia 2009, National Encyclopedia of Bangladesh. Asiatic Society of Bangladesh.

Banik, A.R.1998, 'Management and marketing of rattan based cottage industry in Bangladesh', Journal of Business Studies, IBIUT, Dhaka.

Choudhury, M.R.1984, A study on supply and demand of bamboo and canes in Bangladesh, Food and Agriculture Organization of the United Nations. Rome.

Kotler, P.1997, Marketing management-analysis, planning, implementation and control, 9th edition, Prentice Hall International, . USA Inc, New jersey. 
Mohiuddin, M., M.H. Rashid and Rahman, M.A. 1986, Seed germination and optimal time of transfer of seedlings of calamus spp. From seed bed to polythene bag. Bano Biggyan Patrika, 15(1\&2): 21-24.

Nuruzzaman, M., 2001, A handbook of forest production in Bangladesh. Dhaka: Janata Publication.Patric, B.D., U. Ward and M. Kashio, 1994. Non-wood forest products in asia. FAO, Bangkok.

Rahman, M.M., 2007, 'Marketing of furniture product: A case study on mitsumaru furniture Ltd', Metropolitan University Journal, 1(1).

Shree, S.N., P.B. John, G.R. Lindsay and Jose, 2000, Applications of Geographical Information systems (gis) for spatial decision support in aquaculture. Aquacultural Engineering, 23: 233-278.

Wright Gen, 2008, Understanding more about cane furniture and wicker furniture. Available from www.articelesbase.com. ( accessed on 17.09.2013 